\title{
Economic efficiency of coal gasification in Poland in reference to the price of $\mathrm{CO}_{2}$ emission rights
}

\author{
Michał Kopacz ${ }^{1, a}$ \\ ${ }^{1}$ MEERI PAS, Poland
}

\begin{abstract}
The article presents the impact of prices of carbon dioxide on the economic efficiency of 14 coal gasification technologies employed for producing electricity, hydrogen and methanol measured with the use of NPV method. All technical, technological and economic assumptions in the assessment have been made for Polish conditions. The impact of $\mathrm{CO}_{2}$ prices were examined in the range of 30-200 PLN/Mg. The production capacity of the base technology corresponds with the fuel consumption of indicative coal having the calorific value of 20.5 $\mathrm{GJ} / \mathrm{Mg}$, used in the amount of $100 \mathrm{Mg} / \mathrm{h}$. On the basis of the conducted research, with respect to all technical and economic assumptions, it can be stated that for the base scale there is a clear impact of prices of $\mathrm{CO}_{2}$ emission allowances above the $90 \mathrm{PLN} / \mathrm{Mg} \mathrm{CO}$. Such a level of carbon dioxide prices makes the decision concerning construction of geological sequestration systems (CCS, carbon capture and storage) worthwhile. This applies in particular to the production of electric energy. For the variants focused on hydrogen production there is a dominance of variants with CCS system only at the price exceeding $120 \mathrm{PLN} / \mathrm{Mg} \mathrm{CO}_{2}$, and in the case of methanol such a situation occurs above $150 \mathrm{PLN} / \mathrm{Mg} \mathrm{CO}_{2}$.
\end{abstract}

\section{Introduction}

Gasification of coal has a relatively long history in Poland, although it has never been implemented on industrial scale. Globally, increasing interest in that technology has been noted for the production of power (and heat), hydrogen, or methanol, which are raw materials for chemical synthesis, and further processing $[1,2]$.

Hydrogen is used for the production of ammonia and - further on - chemical fertilizers [3,4]. Ammonia production capacity in Poland is assessed at some $3.0 \mathrm{Tg}$ a year [5]. Methanol, among other things, is used as an intermediate product in MTO processes for production of olefins, gasoline, etc. $[6,7,8]$.

At present, some $40 \mathrm{Tg}$ of hydrogen are produced worldwide every year, which amounts to $1 \%$ of the world demand for primary energy. Increased interest in hydrogen production is also confirmed in the forecasts of EIA and BP; in future one may expect that the increase of demand for natural gas will be most noticeable, with less steep increase of demand for oil and coal [9, 10, 11]. Production of hydrogen by means of coal gasification appears to be also a technology competitive in terms of costs, feasible on industrial scale $[12,3]$.

Gasification of coal belongs to the so-called clean technologies, the aim of which is to minimize the negative influence of energy generation and chemical processes upon the environment. In the processes of methanol synthesis, the amount of carbon dioxide emitted to the atmosphere is reduced [13]. $\mathrm{CO}_{2}$ may also be stored underground, in the processes of geological sequestration, yet the development level of that type of CCS technology is not significant. That development depends on the substantial requirements concerning he place of storage, rock mass, environment, and safety of people on the surface.

\section{Statement of reasons for dealing with the topic}

Below, there are some arguments, which justify the author's interest in coal gasification in Poland, as well as the assessment of the influence of $\mathrm{CO}_{2}$ upon the efficiency of that process:

- there is a substantial interest in coal gasification technologies for production of liquid and gas fuels worldwide, particularly in Asia [14],

- documented recoverable resources of hard coal, as of 31.12.2014, amount to some 52 billion $\mathrm{Mg}$, while those of brown coal (lignite) amount to 23.5 billion $\mathrm{Mg}$ [15],

- the project of the Polish Ministry of Economy, entitled Polityka Energetyczna Polski do 2050 (Energy Policy of Poland until 2050) assumes conducting development studies concerning technologies, the application of which will be advantageous over a longer time, such as: gasification of coal, CCS technology, and

\footnotetext{
a Corresponding author: kopacz@meeri.pl
} 
technologies for utilization of captured carbon dioxide [16],

- the European Commission, in its document entitled Energy 2020 states the aim - reduction of greenhouse gases emission by $80-95 \%$ in 2050 [17]. In the Roadmap 2050 it is proposed to reduce the greenhouse emissions by $80 \%$ by the year 2050 , in comparison with emission level of 1990 (in the entire European Union), stating at the same time the required reduction of greenhouse gas emissions in subsequent years: $25 \%$ in $2020 ; 40 \%-2030$; $60 \%-2040 ; 80 \%-2050$. In order to ensure the achievement of the goals set, the European Union Emissions Trade Scheme (EU ETS) has been envisaged, with the new emission reduction rate of $>1.74 \%$ a year [18],

- Also in the Industrial Emissions Directive (IED) of 2010 [19], measures have been indicated to prevent environmental pollution and to control emission levels.

- In the provisions of the Accession Treat as well as the Climate and Energy Package it is additionally assumed to introduce new standards for construction of new power plants in the CCS-ready system, as well as to conduct research for geological sequestration of $\mathrm{CO}_{2}$.

- In the documents referred to above, it is also indicated that - due to the policy conducted - a significant increase of $\mathrm{CO}_{2}$, prices can be expected, which can result in diminishing the economic efficiency of power generation and chemical undertakings, which will have high levels of carbon dioxide emissions. Road Map 2050 assumes that the price of $\mathrm{CO}_{2}$ emissions allowances in 2030 may exceed $25 \mathrm{EUR}$ per $1 \mathrm{Mg}$ of $\mathrm{CO}_{2}$, whereas in IEA forecasts [20] those prices, depending on the scenario, may increase even to 75 EUR per $1 \mathrm{Mg}$ of $\mathrm{CO}_{2}$.

- Besides the above arguments, professional literature in Polish does not contain many studies, which would analyse the influence of prices of emissions allowances upon the efficiency of coal gasification technologies in a uniform assessment standard, and for common assumptions as to the scale and type of fuel consumed $[21,22,23,24]$. The world professional literature contains studies on efficiency of coal gasification, taking into account the influence of prices of $\mathrm{CO}_{2}$ emissions allowances, conducted among others by: Herzog, Simbeck, Rubin et al. [25, 26, 27]. The results of studies in that respect can also be found on the website of the US Department of Energy [28].

\section{Approach to valuation and key assumptions}

\subsection{Approach to valuation}

Income-based valuation has been used to assess the economic efficiency of the analysed coal gasification technologies - discount model based on the forecast of FCFF (free cash flow to firm). It is preferred when assessing technologies for power generation and chemical processing $[29,30]$. The net present value (NPV) has been calculated, as well as related indicators, such as IRR or NPVR. In the publication, inference has been based solely only NPV.

In the investment outlays, the following have been identified: costs of technological infrastructure of processes, auxiliary infrastructure, construction works, project documentation, or replacement investments. The investment outlays have been calculated at the level of TPC (total plant costs), as well as after consideration of other overheads and provisions (working capital requirements, demand for materials and chemicals in the start-up phase, as well as provisions amounting to $15 \%$ of TPC) - as total as spent costs (TASC) [31].

The calculation of operating costs comprised the cost of fuel used as charge - coal - as well as raw materials and other materials, energy and utilities, services, taxes and fees (real property taxes and insurance premiums, cost of $\mathrm{CO}_{2}$ emission, fees for use of the environment), remuneration and related costs, depreciation, as well as other costs of operation (cost of plant closure, costs of $\mathrm{CO}_{2}$ monitoring, waste management). Costs related to general administration (administration and support) amounted to $30 \%$ of the cost of personnel. On the other hand, the costs of sales have been calculated as TPC overheads in the amount of $0.25 \%$. The costs of taxes and fees have been calculated as $0.7 \%$ of TPC, while the costs of insurance as $0.5 \%$ of TPC. Costs of repairs, servicing, and overhauls are calculated individually. The costs of fixed asset depreciation have been calculated taking into account the depreciation rates used for balance sweet purposes, adjusted to the useful life of a given technology.

The value of revenues has been calculated by multiplying the quantities of main products (electricity, methanol, and hydrogen), as well as respective intermediate products (heat, sulphur), and their prices, in line with assumptions made in table (Tab. 3).

\subsection{Key assumptions}

\subsubsection{Key technical and technological assumptions}

Table 1 shows the mass balance with particular emphasis on the final products and the quantity of $\mathrm{CO}_{2}$ emitted or stored. These calculations are the underlying assumptions in the assessment of economic efficiency of the analysed technologies.

Table 1. Technical and technological assumptions in the assessment - mass balance

\begin{tabular}{|c|c|c|c|c|c|c|c|c|}
\hline $\begin{array}{c}\text { Name of } \\
\text { tech. }\end{array}$ & Coal & CCS & $\begin{array}{c}\text { Final } \\
\text { product }\end{array}$ & $\begin{array}{c}\text { Raw } \\
\text { input } \\
\text { (flow } \\
\text { rate) } \\
\end{array}$ & $\begin{array}{l}\text { Dried } \\
\text { input } \\
\text { (flow } \\
\text { rate) }\end{array}$ & $\begin{array}{c}\text { Capacity } \\
\text { factor }\end{array}$ & $\begin{array}{c}\text { Cal. } \\
\text { value } \\
\text { of dried } \\
\text { coal }\end{array}$ & $\begin{array}{c}\text { Cal. } \\
\text { value } \\
\text { of raw } \\
\text { coal } \\
\end{array}$ \\
\hline \multicolumn{4}{|c|}{ Technology description } & {$[\mathrm{Mg} / \mathrm{h}]$} & {$[\mathrm{Mg} / \mathrm{h}]$} & {$[\%]$} & {$[\mathrm{GJ} / \mathrm{Mg}]$} & {$[\mathrm{GJ} / \mathrm{Mg}]$} \\
\hline Shell & H.c. & 0 & E.en. & 85,1 & 69,0 & $80 \%$ & 24,9 & 20,2 \\
\hline Shell & H.c. & 1 & E.en. & 85,1 & 69,0 & $80 \%$ & 24,9 & 20,2 \\
\hline Shell & B.c. & 0 & E.en. & 161,6 & 85,8 & $80 \%$ & 20,1 & 10,6 \\
\hline Shell & B.c. & 1 & E.en. & 161,6 & 85,8 & $80 \%$ & 20,1 & 10,6 \\
\hline Shell & H.c. & 0 & $\mathrm{H} 2$ & 95,7 & 77,7 & $90 \%$ & 24,9 & 20,2 \\
\hline
\end{tabular}




\begin{tabular}{|c|c|c|c|c|c|c|c|c|}
\hline Shell & H.c. & 1 & $\mathrm{H} 2$ & 95,7 & 77,7 & $90 \%$ & 24,9 & 20,2 \\
\hline Shell & B.c. & 0 & $\mathrm{H} 2$ & 181,8 & 96,5 & $90 \%$ & 20,1 & 10,6 \\
\hline Shell & B.c. & 1 & $\mathrm{H} 2$ & 181,8 & 96,5 & $90 \%$ & 20,1 & 10,6 \\
\hline GE & H.c. & 0 & $\mathrm{H} 2$ & 95,7 & 73,4 & $90 \%$ & 26,4 & 20,2 \\
\hline GE & H.c. & 1 & $\mathrm{H} 2$ & 95,7 & 73,4 & $90 \%$ & 26,4 & 20,2 \\
\hline Shell & H.c. & 0 & $\mathrm{MeOH}$ & 95,7 & 77,7 & $90 \%$ & 24,9 & 20,2 \\
\hline Shell & H.c. & 1 & $\mathrm{MeOH}$ & 95,7 & 77,7 & $90 \%$ & 24,9 & 20,2 \\
\hline Shell & B.c. & 0 & $\mathrm{MeOH}$ & 181,8 & 96,5 & $90 \%$ & 20,1 & 10,6 \\
\hline Shell & B.c. & 1 & $\mathrm{MeOH}$ & 181,8 & 96,5 & $90 \%$ & 20,1 & 10,6 \\
\hline
\end{tabular}

Table 1a. Technical and technological assumptions in the assessment - mass balance (cont.)

\begin{tabular}{|c|c|c|c|c|c|c|c|}
\hline Description & \multirow{2}{*}{ Coal } & CCS & $\begin{array}{c}\text { El. } \\
\text { energy }\end{array}$ & $\mathbf{M e O H}$ & $\mathbf{H 2}$ & $\begin{array}{c}\mathbf{C O}_{2} \\
\text { emission }\end{array}$ & $\begin{array}{c}\mathbf{C O}_{2} \\
\text { stored }\end{array}$ \\
\hline [GJ/h] & {$[\mathrm{kg} / \mathrm{h}]$} & {$[\mathrm{kg} / \mathrm{h}]$} & {$[\mathrm{kg} / \mathrm{h}]$} & {$[\mathrm{kg} / \mathrm{h}]$} \\
\hline Shell & H.c. & 0 & 736 & - & - & 164921 & - \\
\hline Shell & H.c. & 1 & 547 & - & - & 17137 & 147785 \\
\hline Shell & B.c. & 0 & 737 & - & - & 171778 & - \\
\hline Shell & B.c. & 1 & 526 & - & - & 17528 & 154250 \\
\hline Shell & H.c. & 0 & - & - & 9306 & 184850 & - \\
\hline Shell & H.c. & 1 & - & - & 8477 & 20061 & 164789 \\
\hline Shell & B.c. & 0 & - & - & 8421 & 192799 & - \\
\hline Shell & B.c. & 1 & - & - & 7237 & 20643 & 172156 \\
\hline GE & H.c. & 0 & - & - & 7977 & 182764 & - \\
\hline GE & H.c. & 1 & - & - & 6637 & 18431 & 164333 \\
\hline Shell & H.c. & 0 & -161 & 57372 & - & 105662 & - \\
\hline Shell & H.c. & 1 & -254 & 57372 & - & 6465 & 99196 \\
\hline Shell & B.c. & 0 & -177 & 54214 & - & 118024 & - \\
\hline Shell & B.c. & 1 & -276 & 54214 & - & 6110 & 111915 \\
\hline Own study. & & & & & & & \\
\hline
\end{tabular}

The assessment period was 30 years for all the technologies, with the building phase of 3 years. The intensity of the capital expenditures was assumed $20 \%, 45 \%$ and $35 \%$ in the third year.

The useful life comprised the construction phase, operation (26 successive periods/cycles), preceded by the commissioning and start-up (half a year) and one year for liquidation. The manufacturing scale, expressed as the amount of energy at input to the system (equivalent of $100 \mathrm{Mg}$ of coal with the calorific value of $21.5 \mathrm{GJ} / \mathrm{Mg}$ ) was equal for all the technological variants analysed.

Table 2 contains the characteristics of physical and chemical parameters of coal grades that underwent gasification. Grades of similar characteristics may be considered the most frequently occurring in Poland.

Table 2. Elemental composition and energy specifications for hard and brown (lignite) coal

\begin{tabular}{|l|c|c|c|}
\hline Description & U.m. & Hard coal & $\begin{array}{c}\text { Brown coal } \\
\text { /ignite }\end{array}$ \\
\hline humidity & {$[\%]$} & 21.3 & 48.8 \\
\hline coal & {$[\%]$} & 54.26 & 32.00 \\
\hline hydrogen & {$[\%]$} & 3.11 & 2.48 \\
\hline nitrogen & {$[\%]$} & 0.84 & 0.39 \\
\hline chlorine & {$[\%]$} & 0.00 & 0.01 \\
\hline
\end{tabular}

\begin{tabular}{|l|c|c|c|}
\hline Description & U.m. & Hard coal & $\begin{array}{c}\text { Brown coal } \\
\text { lignite }\end{array}$ \\
\hline sulphur & {$[\%]$} & 1.10 & 0.03 \\
\hline ash & {$[\%]$} & 9.30 & 5.49 \\
\hline oxygen & {$[\%]$} & 10.09 & 10.80 \\
\hline \multicolumn{4}{|c|}{ Calorific value } \\
\hline High heat value HHV & {$[\mathrm{GJ} / \mathrm{Mg}]$} & 21.43 & 12.39 \\
\hline Low heat value LHV & {$[\mathrm{GJ} / \mathrm{Mg}]$} & 20.22 & 10.65 \\
\hline Own study.
\end{tabular}

Gasification process in Shell technology is based on entrained-flow gasifier operating at full commercial scale. Gasification reaction takes place at $4.2 \mathrm{MPa}$ and $1430^{\circ} \mathrm{C}$ to produce syngas. The Shell process uses a dry feed system (hard coal is crashed and dried to $6 \%$ of moisture and the lignite to $12 \%$ ). The product gas from the gasifier is cooled using a syngas recycle quench. Syngas goes through a raw gas cooler, which lowers the gas temperature to a minimum of $230^{\circ} \mathrm{C}\left(450^{\circ} \mathrm{F}\right)$, and contributes to the production of high pressure steam for use in the steam cycle. The solids and liquid slag formed in a water bath are removed through a lock hopper system. Ash carried over with the syngas is removed in a ceramic candle filter. Syngas enters the scrubber for removal of chlorides and entrained particles, principally unconverted carbon, slag and metals. In the acid gas removal process, COS hydrolysis, mercury clean-up about 15 percent of the $\mathrm{CO}_{2}$ along with the $\mathrm{H}_{2} \mathrm{~S}$ and COS is removed. The residual $\mathrm{CO}_{2}$ passes through the SRU, the hydrogenation reactor and is recycled to the AGR. The SRU utilises oxygen instead of air. The Claus plant produces sulphur, of witch recovery exceeds $99 \%$. Clean syngas exiting the sulfinol absorber is reheated, diluted with nitrogen from the ASU, and enters the advanced F-Class gas turbine in the IGCC plant. Then exhaust gas is transported to the HRSG where additional heat is recovered. The steam form the HRSG is delivered to the steam turbine and generator.

In the case of Shell hydrogen production the watergas-shift reactor provides the optimal syngas composition. Hydrogen is separated with an efficiency of $80 \%$ and is purified to the required level of $99.9 \%$. Tail gas is burned in the CT burner to produce heat and vapour for the turbine generator.

However, in the case of methanol production, cleaned syngas is sent to the methanol synthesis unit. Raw methanol is then subjected to purification ( $99.9 \%$ pure). The tail gas is combusted in a flare, or if it is sufficiently rich in combustible components, passes through the boiler and the turbine connected to the generator (fig. 1).

In the case of the General Electric hydrogen production plant a wet feed system is used and gasification process occurs at a temperature of $1320^{\circ} \mathrm{C}$ and pressure of 5,6 MPa. The oxidant is $99 \%$ oxygen separated in the ASU. Raw synthetic gas is then transported to battery filters and cyclones to remove particles, $\mathrm{NH}_{3}, \mathrm{SO}_{2}$ and other impurities and in the quench water system and scrubbers is cooled to $230^{\circ} \mathrm{C}$. The $99,9 \%$ of particles, $90 \%$ of chlorides and the alkaline compounds are removed so far. 
The water-gas-shift reaction takes place at $5.4 \mathrm{MPa}$ enhancing the amount of

$\mathrm{H}_{2}$. After WGS conversion syngas is cooled to $35^{\circ} \mathrm{C}$ and cleaned of mercury, acid components (COS) in the selexol unit. Hydrogen is separated at a level of $80 \%$ and purified to $99,9 \%$. The tail gas is combusted in the boiler, and steam produced enters the turbine connected to the generator.
For technologies with the $\mathrm{CCS}, \mathrm{CO}_{2}$ extracted from syngas is compressed and then with the pipeline system is transported assuming geological sequestration.

In both technologies, the exhaust gases having a temperature of $140^{\circ} \mathrm{C}$ are sent to the chimney (fig 2).

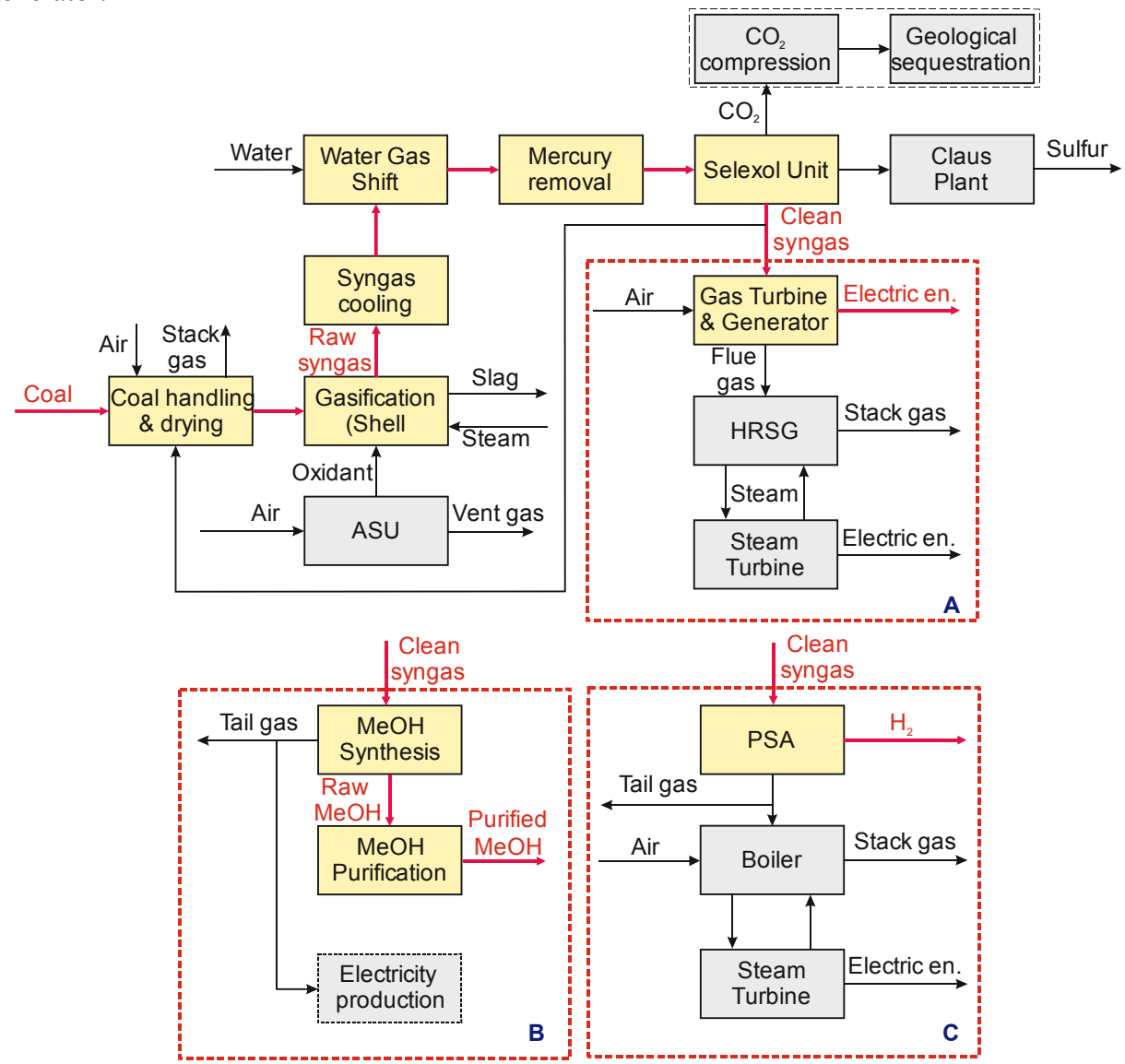

Figure 1. Block diagram of the Shell technology; A - electric energy, B - methanol, C - hydrogen production. Own study.

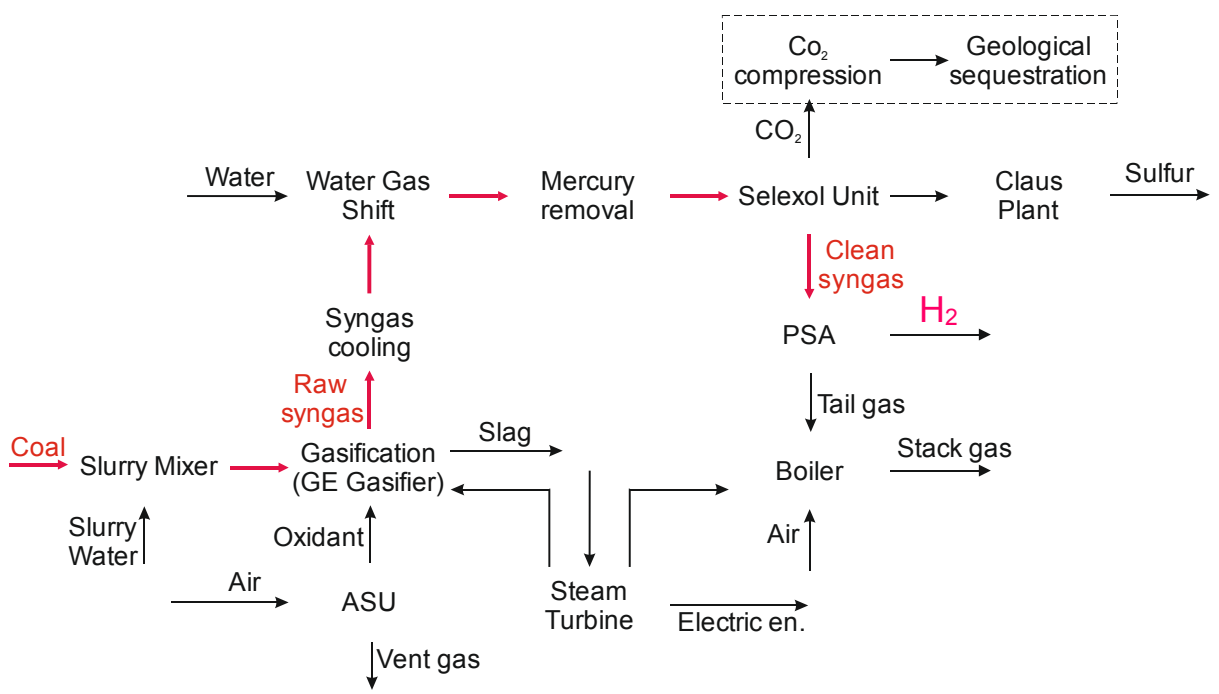

Figure. 2. Block diagram of the General Electric technology; hydrogen production. Own study 


\subsubsection{Key economic and financial assumptions}

Table 3 contains the key macroeconomic assumptions, which serve the purpose of evaluating the analysed technological variants of coal gasification. All the calculations have been made in nominal terms (the detailed forecast comprised 10 consecutive one year periods). The prices of specific end products and of coal have been estimated according to individual growth paths (Tab. 3).

Table 3. Gasification of coal to produce electricity

\begin{tabular}{|l|c|c|}
\hline \multicolumn{1}{|c|}{ Description } & 2015 & $\begin{array}{c}\text { Assumptions } \\
\text { in 2016-2025 }\end{array}$ \\
\hline Inflation CPI & $1.1 \%$ & $\begin{array}{c}2016:+1.6 \% ; \\
2017-2025: \\
+2.5 \%\end{array}$ \\
\hline Price of hard coal & $197.0[\mathrm{PLN} / \mathrm{Mg}](9.74 \mathrm{PLN} / \mathrm{GJ}$ & $+0.25 \% \mathrm{y} / \mathrm{y}$ \\
\hline Price of brown coal & $76.6[\mathrm{PLN} / \mathrm{Mg}](7.2 \mathrm{PLN} / \mathrm{GJ})$ & $+0.3 \% \mathrm{y} / \mathrm{y}$ \\
\hline Price of methanol & $1,450[\mathrm{PLN} / \mathrm{Mg}]$ & $+1.25 \% \mathrm{y} / \mathrm{y}$ \\
\hline Price of hydrogen & $7,400[\mathrm{PLN} / \mathrm{Mg}]$ & $+0.75 \% \mathrm{y} / \mathrm{y}$ \\
\hline Price of electricity (sold) & $170.0[\mathrm{PLN} / \mathrm{MWh}]$ & $+1 \% \mathrm{y} / \mathrm{y}$ \\
\hline Price of electricity (buy) & $290.0[\mathrm{PLN} / \mathrm{MWh}]$ & $+1 \% \mathrm{y} / \mathrm{y}$ \\
\hline Price of natural gas & $1.11\left[\mathrm{Nm}{ }^{3}\right](110 \mathrm{PLN} / \mathrm{MWh})$ & $+0.25 \% \mathrm{y} / \mathrm{y}$ \\
\hline Price of $\mathrm{CO}_{2}$ allowance & $30.0[\mathrm{PLN} / \mathrm{Mg}]$ & $+1 \% \mathrm{y} / \mathrm{y}$ \\
\hline Financing & \multicolumn{3}{|c|}{$50 \%$ of Debt } \\
\hline Risk & RADR (risk adjusted discount rate 6-10\%) \\
\hline Own study.
\end{tabular}

It has been assumed in the analyses that $50 \%$ of the capital expenditures will be financed by a loan, having the interest rate of $5.84 \%$ p.a. The discount rate has been assessed individually for each variant analysed by experts, while the results of such assessment are presented in Table 4. Variants with CCS demonstrate higher risk (premium of 2-3\%), due to the fact that those technologies are not so advanced in Poland, for the time being.

Table. 4. Risk assessment and discount rates (RADR)

\begin{tabular}{|c|c|c|c|c|c|c|c|}
\hline Sp. & Tech. & Coal & CCS & $\begin{array}{c}\text { Final } \\
\text { product }\end{array}$ & $\begin{array}{c}\text { Base } \\
{[\%]}\end{array}$ & $\begin{array}{c}\text { Risk } \\
\text { premium } \\
{[\%]}\end{array}$ & RADR \\
\hline 1 & Shell & H.c. & 0 & El.en. & $4.2 \%$ & $1.8 \%$ & $\mathbf{6 . 0 \%}$ \\
\hline 2 & Shell & B.c. & 0 & El.en. & $4.4 \%$ & $1.8 \%$ & $\mathbf{6 . 2 \%}$ \\
\hline 3 & Shell & H.c. & 1 & El.en. & $5.3 \%$ & $3.7 \%$ & $\mathbf{9 . 0 \%}$ \\
\hline 4 & Shell & B.c. & 1 & El.en. & $5.3 \%$ & $3.7 \%$ & $\mathbf{9 . 0 \%}$ \\
\hline 5 & Shell & H.c. & 0 & $\mathrm{H}_{2}$ & $4.2 \%$ & $1.7 \%$ & $\mathbf{5 . 9 \%}$ \\
\hline 6 & Shell & B.c. & 0 & $\mathrm{H}_{2}$ & $4.2 \%$ & $1.7 \%$ & $\mathbf{5 . 9 \%}$ \\
\hline 7 & Shell & H.c. & 1 & $\mathrm{H}_{2}$ & $5.3 \%$ & $3.7 \%$ & $\mathbf{9 . 0 \%}$ \\
\hline 8 & Shell & B.c. & 1 & $\mathrm{H}_{2}$ & $5.3 \%$ & $3.7 \%$ & $\mathbf{9 . 0 \%}$ \\
\hline 9 & GE & H.c. & 1 & $\mathrm{H}_{2}$ & $5.3 \%$ & $3.6 \%$ & $\mathbf{8 . 9 \%}$ \\
\hline 10 & GE & H.c. & 0 & $\mathrm{H}_{2}$ & $4.2 \%$ & $1.8 \%$ & $\mathbf{6 , 0 \%}$ \\
\hline 11 & Shell & H.c. & 0 & $\mathrm{MeOH}$ & $4.2 \%$ & $1.7 \%$ & $\mathbf{5 . 9 \%}$ \\
\hline 12 & Shell & B.c. & 0 & $\mathrm{MeOH}$ & $4.2 \%$ & $1.7 \%$ & $\mathbf{5 . 9 \%}$ \\
\hline 13 & Shell & H.c. & 1 & $\mathrm{MeOH}$ & $5.3 \%$ & $3.7 \%$ & $\mathbf{9 . 0} \%$ \\
\hline 14 & Shell & B.c. & 1 & $\mathrm{MeOH}$ & $5.3 \%$ & $3.7 \%$ & $\mathbf{9 . 0} \%$ \\
\hline
\end{tabular}

Table 5 presents the investment outlays related to construction of installations. Additionally, the expenditures concerning geological sequestration of carbon dioxide have been specified (if applicable). In case of $\mathrm{CO}_{2}$ storage, its previous compression has been assumed and transport by pipeline along a distance of some $80 \mathrm{~km}$. The investment outlays are in the range of 2.91-3.91 billion PLN. The investment costs concerning CCS module amount from 300 to 430 million PLN, depending on the variant.

Table 5. Capital expenditure for the coal gasification technologies - electricity production [mln PLN]

\begin{tabular}{|l|c|c|c|c|}
\hline \multirow{3}{*}{ Description } & \multicolumn{4}{|c|}{ Shell technologies } \\
\cline { 2 - 5 } & \multicolumn{2}{|c|}{ Hard coal } & \multicolumn{1}{c|}{ Brown coal/Lignite } \\
\cline { 2 - 5 } & w/o CCS & CCS & w/o CCS & CCS \\
\hline Total Capex & 2990 & 3450 & 3440 & 3910 \\
\hline Capex for CCS & - & 390 & - & 400 \\
\hline
\end{tabular}

Own study.

Table 5a. Capital expenditure for the coal gasification technologies - hydrogen production [mln PLN]

\begin{tabular}{|c|c|c|c|c|c|c|}
\hline \multirow{3}{*}{ Description } & \multicolumn{4}{|c|}{ Shell technologies } & \multirow{2}{*}{\multicolumn{2}{|c|}{$\begin{array}{c}\begin{array}{c}\text { GE } \\
\text { technologies }\end{array} \\
\text { Hard coal } \\
\end{array}$}} \\
\hline & \multicolumn{2}{|c|}{ Hard coal } & \multicolumn{2}{|c|}{$\begin{array}{c}\text { Brown } \\
\text { coal/Lignite }\end{array}$} & & \\
\hline & w/o CCS & CCS & w/o CCS & CCS & w/o CCS & CCS \\
\hline Total Capex & 2910 & 3400 & 3510 & 4010 & 2680 & 3160 \\
\hline $\begin{array}{l}\text { Capex for } \\
\text { CCS }\end{array}$ & - & 420 & - & 430 & - & 420 \\
\hline
\end{tabular}

Table 5b. Capital expenditure for the coal gasification technologies - methanol production [mln PLN]

\begin{tabular}{|l|c|c|c|c|}
\hline \multirow{3}{*}{ Description } & \multicolumn{4}{|c|}{ Shell technologies } \\
\cline { 2 - 5 } & \multicolumn{2}{|c|}{ Hard coal } & \multicolumn{1}{|c|}{ Brown coal/Lignite } \\
\cline { 2 - 5 } & w/o CCS & CCS & w/o CCS & CCS \\
\hline Total Capex & 2900 & 3200 & 3240 & 3570 \\
\hline Capex for CCS & - & 300 & - & 330 \\
\hline
\end{tabular}

Own study.

Table 6 contains the key assumptions used calculation of operating costs pertaining to the consumption of chemicals and materials, whereas Table 6a, respectively, contains the assumptions for salary cost estimation. Total employment amounted to 50 people (including 24 persons of maintenance personnel and 3 persons of technical inspection).

Table 6. Costs of production - key assumptions

\begin{tabular}{|l|c|r|}
\hline \multicolumn{1}{|c|}{ Description } & U.m. & \multicolumn{1}{c|}{ Value } \\
\hline Carbon (Mercury Removal) & {$[\mathrm{PLN} / \mathrm{kg}]$} & 12.6 \\
\hline Claus catalyst & {$\left[\mathrm{PLN} / \mathrm{m}^{3}\right]$} & 23,500 \\
\hline COS catalyst & {$\left[\mathrm{PLN} / \mathrm{m}^{3}\right]$} & 13,000 \\
\hline MU \& WT chem. & {$[\mathrm{PLN} / \mathrm{kg}]$} & 2.1 \\
\hline Slag & {$[\mathrm{PLN} / \mathrm{Mg}]$} & 30.0 \\
\hline Spent mercury catalyst & {$[\mathrm{PLN} / \mathrm{kg}]$} & 5.0 \\
\hline Sulfinol solution & {$[\mathrm{PLN} / \mathrm{l}]$} & 9.5 \\
\hline
\end{tabular}




\begin{tabular}{|l|c|r|}
\hline \multicolumn{1}{|c|}{ Description } & U.m. & \multicolumn{1}{c|}{ Value } \\
\hline Water & {$\left[\mathrm{PLN} / \mathrm{m}^{3}\right]$} & 1.3 \\
\hline Water gas shift catalyst & {$\left[\mathrm{PLN} / \mathrm{m}^{3}\right]$} & $90,000.0$ \\
\hline Selexol solution & {$[\mathrm{PLN} / 1]$} & 33.5 \\
\hline
\end{tabular}

Own study.

Tabela 6a. Labour costs - key assumptions

\begin{tabular}{|l|c|r|}
\hline \multicolumn{1}{|c|}{ Description: labour } & U.m. & \multicolumn{1}{c|}{ Cost } \\
\hline Operator & {$[\mathrm{PLN} / \mathrm{mth}]$} & 5,000 \\
\hline Skilled operator & {$[\mathrm{PLN} / \mathrm{mth}]$} & 10,000 \\
\hline Foremen and administration & {$[\mathrm{PLN} / \mathrm{mth}]$} & 12,000 \\
\hline Own study.
\end{tabular}

\section{Results of studies}

Tables 7, 8, and 9 show the results of assessing the economic efficiency of coal gasification, as well as recommendation of the most favourable investment decisions, as regards the generation of carbon dioxide. Also the assessment of NPV result sensitivity to the change in the price of $\mathrm{CO}_{2}$ emissions allowances in the range of 30-200 PLN/Mg has been added.

When Table 7 is analysed, one can notice that for the assumptions made - the technologies of hard coal and lignite gasification to produce electricity are not efficient. At the price of $\mathrm{CO}_{2}$ emissions allowances below $90 \mathrm{PLN} / \mathrm{Mg}$ of carbon dioxide, it is more profitable to emit the gas to the atmosphere. Only when the price exceeds $120 \mathrm{PLN} / \mathrm{Mg}$ of $\mathrm{CO}_{2}$, efficiency advantage measured by means NPV is gained by the variants with CCS. The sensitivity of NPV results in case of gasification for power generation from coal grades analysed was relatively low, which is due to the conditions of the valuation model and low NPV values in the base scenario $\left(\mathrm{CO}_{2}\right.$ emissions allowance trading at $30 \mathrm{PLN} / \mathrm{Mg}$ ).

Table 7. Gasification of coal for power generation

\begin{tabular}{|c|c|c|c|c|}
\hline \multirow{3}{*}{ Description } & \multicolumn{4}{|c|}{ Shell Technology } \\
\hline & \multicolumn{2}{|c|}{ Hard coal } & \multicolumn{2}{|c|}{ Brown coal/Lignite } \\
\hline & w/o CCS & CCS & w/o CCS & CCS \\
\hline $\mathrm{CO}_{2}$ price $[\mathrm{PLN} / \mathrm{Mg}]$ & \multicolumn{4}{|c|}{ NPV [FCFF] [mIn PLN] } \\
\hline 30 (ref. Scen) & -2818 & -3952 & -3014 & -4338 \\
\hline 60 & -3325 & -3994 & -3542 & -4380 \\
\hline 90 & -3831 & -4036 & -4070 & -4423 \\
\hline 120 & -4338 & -4077 & -4597 & -4466 \\
\hline 150 & -4844 & -4119 & -5125 & -4508 \\
\hline 200 & -5689 & -4189 & -6004 & -4579 \\
\hline $\mathrm{CO}_{2}$ price $[\mathrm{PLN} / \mathrm{Mg}]$ & \multicolumn{4}{|c|}{ Decision to invest } \\
\hline 30 (ref. Scen) & \multirow{3}{*}{ EU ETS } & \multirow[b]{3}{*}{-} & \multirow{3}{*}{ EU ETS } & \\
\hline 60 & & & & \\
\hline 90 & & & & \\
\hline 120 & \multirow[t]{3}{*}{ - } & \multirow{3}{*}{ CCS } & \multirow{3}{*}{ - } & \multirow{3}{*}{ CCS } \\
\hline 150 & & & & \\
\hline 200 & & & & \\
\hline $\mathrm{CO}_{2}$ price $[\mathrm{PLN} / \mathrm{Mg}]$ & \multicolumn{4}{|c|}{ NPV sensitivity (to reference scenario) } \\
\hline 60 & $18 \%$ & $1 \%$ & $18 \%$ & $1 \%$ \\
\hline 90 & $36 \%$ & $2 \%$ & $35 \%$ & $2 \%$ \\
\hline 120 & $54 \%$ & $3 \%$ & $53 \%$ & $3 \%$ \\
\hline
\end{tabular}

\begin{tabular}{|c|c|c|c|c|}
\hline \multirow{2}{*}{ Description } & \multicolumn{3}{|c|}{ Shell Technology } \\
\cline { 2 - 5 } & \multicolumn{2}{|c|}{ Hard coal } & \multicolumn{2}{c|}{ Brown coal/Lignite } \\
\cline { 2 - 5 } & w/o CCS & CCS & w/o CCS & CCS \\
\hline 150 & $72 \%$ & $4 \%$ & $70 \%$ & $4 \%$ \\
\hline 200 & $102 \%$ & $6 \%$ & $99 \%$ & $6 \%$ \\
\hline Own study.
\end{tabular}

In case of gasification of coal to hydrogen, all the technological variants are also inefficient, taking into consideration the NPV criterion and assessment conditions. It can be stated that generally better results are achieved in case of hard coal gasification using the technology of Shell than that of General Electric (GE). Higher NPV values have been achieved in case of hard coal gasification. The analysis of Table 8 leads to the conclusion that only in case of prices of $\mathrm{CO}_{2}$ emissions allowances exceeding 120 PLN/Mg, the decisions concerning construction of CCS are justified (in case of lower prices, the purchase of emissions allowances is more advantageous). The net present value is particularly sensitive to changes in the emissions allowances price level, in particular for those variants, for which the economic efficiency measured by means of the NPV indicator is close to 0 .

Table 8. Coal gasification to hydrogen

\begin{tabular}{|c|c|c|c|c|c|c|}
\hline \multirow{3}{*}{ Description } & \multicolumn{4}{|c|}{ Shell Technology } & \multirow{2}{*}{\multicolumn{2}{|c|}{$\begin{array}{c}\begin{array}{c}\text { GE } \\
\text { Technology }\end{array} \\
\text { Hard coal } \\
\end{array}$}} \\
\hline & \multicolumn{2}{|c|}{ Hard coal } & \multicolumn{2}{|c|}{$\begin{array}{c}\text { Brown } \\
\text { coal/Lignite }\end{array}$} & & \\
\hline & $\begin{array}{l}\text { w/o } \\
\text { CCS }\end{array}$ & CCS & $\begin{array}{l}\text { w/o } \\
\text { CCS }\end{array}$ & CCS & $\begin{array}{l}\text { w/o } \\
\text { CCS }\end{array}$ & CCS \\
\hline $\begin{array}{c}\mathrm{CO}_{2} \text { price } \\
{[\mathrm{PLN} / \mathrm{Mg}]}\end{array}$ & \multicolumn{6}{|c|}{ NPV [FCFF] [mln PLN] } \\
\hline 30 (ref. Scen) & -339 & -1497 & -1040 & -2547 & -745 & -2185 \\
\hline 60 & -687 & -1531 & -1470 & -2597 & \begin{tabular}{|l|l|}
-1 & 149 \\
\end{tabular} & -2230 \\
\hline 90 & -1061 & -1566 & -2046 & -2648 & -1701 & -2275 \\
\hline 120 & -1567 & -1601 & -2638 & -2698 & -2262 & -2320 \\
\hline 150 & -2135 & -1636 & -3231 & -2748 & -2824 & -2364 \\
\hline 200 & -3081 & -1696 & -4218 & -2832 & -3759 & -2439 \\
\hline $\begin{array}{c}\mathrm{CO}_{2} \text { price } \\
{[\mathrm{PLN} / \mathrm{Mg}]}\end{array}$ & \multicolumn{6}{|c|}{ Decision to invest } \\
\hline 30 (ref. Scen) & \multirow{4}{*}{$\begin{array}{c}\text { EU } \\
\text { ETS }\end{array}$} & \multirow{4}{*}{ - } & \multirow{4}{*}{$\begin{array}{c}\text { EU } \\
\text { ETS }\end{array}$} & & \multirow{4}{*}{$\begin{array}{c}\text { EU } \\
\text { ETS }\end{array}$} & \multirow{4}{*}{ - } \\
\hline 60 & & & & & & \\
\hline 90 & & & & & & \\
\hline 120 & & & & & & \\
\hline 150 & \multirow[t]{2}{*}{ - } & \multirow{2}{*}{ CCS } & & \multirow{2}{*}{$\mathrm{CCS}$} & & \multirow{2}{*}{ CCS } \\
\hline 200 & & & & & & \\
\hline $\begin{array}{l}\mathrm{CO}_{2} \text { price } \\
{[\mathrm{PLN} / \mathrm{Mg}]}\end{array}$ & \multicolumn{6}{|c|}{ NPV sensitivity (to reference scenario) } \\
\hline 60 & $103 \%$ & $2 \%$ & $41 \%$ & $2 \%$ & $54 \%$ & $2 \%$ \\
\hline 90 & $213 \%$ & $5 \%$ & $97 \%$ & $4 \%$ & $128 \%$ & $4 \%$ \\
\hline 120 & $363 \%$ & $7 \%$ & $154 \%$ & $6 \%$ & $204 \%$ & $6 \%$ \\
\hline 150 & $530 \%$ & $9 \%$ & $211 \%$ & $8 \%$ & $279 \%$ & $8 \%$ \\
\hline 200 & $809 \%$ & $13 \%$ & $306 \%$ & $11 \%$ & $405 \%$ & $12 \%$ \\
\hline
\end{tabular}

In case of gasification of selected grades of coal to methanol, the base variant - for the emissions allowances price of about $30 \mathrm{PLN} / \mathrm{Mg} \mathrm{CO}$, assumed prices of coal and methanol over the next 30 years generates the positive value of NPV at the level of 135 million PLN. In other cases the net present value was negative. Only in case of lignite (brown coal) gasification 
and prices of emission allowances exceeding $150 \mathrm{PLN} / \mathrm{Mg}$ of $\mathrm{CO}_{2}$ the option of constructing CCS has an efficiency advantage. NPV sensitivity to the change of emission allowances varies depending on the variant. The highest level NPV variability is demonstrated for those variants, for which the base NPV was relatively close to 0 . The least sensitivity is demonstrated by the variants with strongly negative NPV (they include CCS systems, and the emission to air does not exceed $10 \%)$.

Table 9. Coal gasification to methanol

\begin{tabular}{|c|c|c|c|c|}
\hline \multirow{3}{*}{ Description } & \multicolumn{4}{|c|}{ Shell Technology } \\
\hline & \multicolumn{2}{|c|}{ Hard coal } & \multicolumn{2}{|c|}{ Brown coal/ Lignite } \\
\hline & w/o CCS & $\mathrm{CCS}$ & w/o CCS & CCS \\
\hline $\mathrm{CO}_{2}$ price $[\mathrm{PLN} / \mathrm{Mg}]$ & \multicolumn{4}{|c|}{ NPV [FCFF] [mIn PLN] } \\
\hline 30 (ref. Scen) & 135 & -1072 & -261 & -1513 \\
\hline 60 & -64 & -1082 & -483 & -1523 \\
\hline 90 & -263 & -1093 & -708 & -1533 \\
\hline 120 & -462 & -1103 & -938 & -1543 \\
\hline 150 & -664 & -1113 & -1188 & -1553 \\
\hline 200 & -1021 & -1130 & -1716 & -1571 \\
\hline $\mathrm{CO}_{2}$ price $[\mathrm{PLN} / \mathrm{Mg}]$ & \multicolumn{4}{|c|}{ Decision to invest } \\
\hline 30 (ref. Scen) & \multirow{6}{*}{ EU ETS } & \multirow{6}{*}{ - } & \multirow{5}{*}{ EU ETS } & \multirow{5}{*}{ - } \\
\hline 60 & & & & \\
\hline 90 & & & & \\
\hline 120 & & & & \\
\hline 150 & & & & \\
\hline 200 & & & - & CCS \\
\hline $\mathrm{CO}_{2}$ price $[\mathrm{PLN} / \mathrm{Mg}]$ & \multicolumn{4}{|c|}{ NPV sensitivity (to reference scenario) } \\
\hline 60 & $148 \%$ & $1 \%$ & $85 \%$ & $1 \%$ \\
\hline 90 & $295 \%$ & $2 \%$ & $171 \%$ & $1 \%$ \\
\hline 120 & $443 \%$ & $3 \%$ & $259 \%$ & $2 \%$ \\
\hline 150 & $593 \%$ & $4 \%$ & $354 \%$ & $3 \%$ \\
\hline 200 & $858 \%$ & $5 \%$ & $557 \%$ & $4 \%$ \\
\hline
\end{tabular}

Own study.

\section{Summary and conclusions}

The study presents the results of economic efficiency assessment for 14 technological variants of hard and brown coal (lignite) gasification to produce electricity, hydrogen, and methanol. Higher NPV was decisive for the selection of a more advantageous economic decision (purchase of EU ETS or construction of CCS system). In the entire assessment process, also other criteria of costs, values, or risks have been considered, such as: COE - cost of electricity, LCOE, yearly costs of operations, investment outlays (also individual ones), levels of $\mathrm{CO}_{2}$ emission, dynamic discount rate, RADR (risk-adjusted discount rate), IRR, or NPVR, they have not been presented in this paper, though. The entire results of analyses may be found in [24].

The analysis concerned technological solutions of two producers, namely Shell and General Electric (Texaco).

The analyses conducted allow to state that for the assumed scale of energy consumption analysis in the charge fuel, parameters of selected coal grades, and specified prices of end products of gasification, most of the technological variants failed to obtain efficiency confirmation, using NPV as base. Only one variant of hard coal gasification achieved the NPV value of nearly 135 million PLN. However, this is a case in which the entire fuel is converted into end products, while the internal consumption is covered by external purchase of electricity. In case of gasification for power generation, at allowances prices exceeding $90 \mathrm{PLN} / \mathrm{Mg}$ of $\mathrm{CO}_{2}$, geological sequestration of carbon dioxide seems to be more advantageous. In case of hydrogen production, the justification for decision change occurs at the allowance price of $120 \mathrm{PLN}$ per $1 \mathrm{Mg}$ of $\mathrm{CO}_{2}$ or higher. In case of methanol, only the allowance price level higher than $150 \mathrm{PLN} / \mathrm{Mg}$ of $\mathrm{CO}_{2}$ may justify decisions to invest in the construction of CCS systems.

The results sensitivity of NPV to change of the price level of $\mathrm{CO}_{2}$ emissions allowances differs in different variants, with the most significant changes occurring in case of methanol production, similar in case of methanol, and less profound in case of electricity.

In conclusion, one can state that the assumptions of rigorous requirements concerning $\mathrm{CO}_{2}$ emission limits, which result in significant increases of the emissions allowance price, may greatly influence the assessment of coal gasification efficiency. This applies in particular to the production of electricity and hydrogen. In case of methanol production, a part of $\mathrm{CO}_{2}$ is bound in end products, which significantly enhances the efficiency and attractiveness of $\mathrm{MeOH}$ generation. A significant increase of the price of emissions allowances will also result in substantial reduction of attractiveness of investment in conventional power engineering and heat generation.

\section{References}

1. T. Borowiecki, J. Kijeński, J. Machnikowski, M. Sciążko: Czysta energia, produkty chemiczne i paliwa z węla - ocena potencjału rozwojowego. Wyd. ICHPW, Zabrze 2008.

2. M. Taniewski, Przemysł Chemiczny, (91/4), str. 492498 (2012),

3. K. McHugh, S. Eisele, J. Nestell: Hydrogen production methods, MPR Associates, Inc. MPRWP-0001, (2005).

4. T. Chmielniak, Badania symulacyjne technologii wytwarzania wodoru $w$ aspekcie emisji $\mathrm{CO}_{2}-$ wydobycie, transport $i$ przetwórstwo wegla, Wydawnictwo Politechniki Śląskiej, Gliwice, (2014),

5. W. Lubiewa-Wieleżyński: Prognozy rozwoju przemystu chemicznego w Polsce do 2020 roku, Warszawa, (październik 2014), materiał niepublikowany.

6. UOP LLC, Methanol to olefins, IOCL Conclave, Des Plaines, Illinois, USA, 2014.

7. M. Taniewski, Przemysł Chemiczny, (92/2), str. 140147, (2013),

8. R. Luque, J. Speight: Gasification for syntetic fuel production, Woodland Publishing Series In Energy, 69, Elsevier Ltd. (2015), 
9. BP, British Petroleum: Energy Outlook 2035, http://www.bp.com/content/dam/bp/pdf/energyeconomics/energy-outlook-2015/bp-energy-outlook2035-booklet.pdf, on-line (15.04.2016),

10. J. B. Tennant: Gasification Systems Overview, US Department of Energy, National Energy Technology Laboratory, http://www.netl.doe.gov/File\%20Library/Research/C oal/energy\%20systems/gasification/doe-gasificationprogram-overview.pdf , (on-line 15.04.2016)

11. EIA, U.S. Energy Information Administration: Annual Energy Outlook 2015 with projections to 2040.: http://www.eia.gov/forecasts/aeo/, (on-line 15.04.2016)

12. IEA, International Energy Agency: Energy Technology Essentials - Biofuel Production, Jan. 2007 ,

https://www.iea.org/publications/freepublications/pu blication/essentials2.pdf, (on-line 15.04.2016),

13. M. Ściążko, J. Kijeński red.: Studium koncepcyjne wybranych technologii, perspektywicznych procesów i produktów konwersji węgla - osiagnięcia i kierunki badawczo-rozwojowe. Zgazowanie węgla, Tom 1. Wyd. ICHPW, Zabrze 2010,

14. C. Higman, State of the Gasification Industry the Update Worldwide Gasification Database, International Pittsburgh Coal Conference, Beijng, China, (2013),

15. PIG, Państwowy Instytut Geologiczny, Bilans zasobów PLNóż kopalin w Polsce wg. stanu na 31.12.2013, Warszawa, (2014).

16. MG, Projekt Polityki Energetycznej do roku 2050, Ministerstwo Gospodarki RP 2014, www.mg.gov.pl (on-line 15.04.2016),

17. EC, European Commission: Energy 2020. A strategy for competitive, sustainable and secure energy, $\operatorname{KOM}(2010) 639$, (2010).

18. EC, European Commission: Energy Roadmap 2050; KOM (2011) 885/2, (2011),

19. EC, European Commission: EC, Industry Emission Directive. 2010/75/EU, (November 2010),

20. IEA, International Energy Agency, The World Energy Outlook 2014. Paris. France, http://www.worldenergyoutlook.org/weo2014/, (on-line 15.04.2016),

21. M. Ściążko, L. Zapart, K. Dreszer, Polityka Energetyczna, IGSMiE PAN, 9, special editon, (2006)

22. K. Stańczyk K, M. Bieniecki, Górnictwo i Geoinżynieria, 2/31, pp. 575-586, (2007)

23. K. Janusz-Szymańska, Rynek Energii, 5/2012, str. 24-30, (2012),

24. K. Kwaśniewski, M. Kopacz, P. Grzesiak, R. Kapłan, E.J. Sobczyk, Coal gasification conditions, effectiveness and perspectives for development, Wydawnictwa AGH, Kraków, (2015)

25. H. Herzog, Greenhouse Gas Control Technologies, Elsevier Science Ltd., pp. 101-106 (1999).

26. D.R. Simbeck, $\mathrm{CO}_{2}$ Mitigation Economics for Existing Coal-Fired Power Plants. Paper read at Pittsburgh Coal Conference, NSW, Australia. (Dec.4 2001),

27. E.S. Rubin, C. Chen, A.B. Rao, 2007, Energy Policy, 35(9), 4444-4454 (2007),

28. DOE NETL: Advanced $\mathrm{CO}_{2}$ Capture R\&D Program; Advanced CO2 Capture R\&D Program, http://www.netl.doe.gov/research/coal/carboncapture/capture-handbook (on-line 15.04.2016),

29. K. K. Humphreys, S. Katell: Basic cost engineering. Marcel Dekker Inc, New York, (1981)

30. K. Kwaśniewski, M. Kopacz, P. Grzesiak, R. Kapłan, D. Kryzia, Przemysł Chemiczny 95/1, str. 130-137, (2016),

31. DOE NETL: Quality guidelines for Energy System Studies: Cost Estimation Methodology for NETL Assessments for Power Plant Performance: DOE/NETL-2011/1455, (April 2011), 